International Business Management 13 (9): 381-391, 2019

ISSN: $1993-5250$

(C) Medwell Journals, 2019

\title{
Analysis of the Variability of Interest Rate Structure on Corporate Financial Investment Decisions: The Nigerian Perspective
}

\author{
${ }^{1}$ Onuoha Ijeoma Perpetua, ${ }^{1}$ Uwakwe Theresa, Nnenna \\ ${ }^{1}$ Oko Roseline Ali and ${ }^{2}$ Obi Chinazor Franca \\ ${ }^{1}$ Department of Accountancy and Banking and Finance, \\ Alex-Ekwueme Federal University Ndufu-Alike Ikwo, Ebonyi State, Nigeria \\ ${ }^{2}$ Department of Business Administration, Alex-Ekwueme Federal University Ndufu-Alike Ikwo, \\ Ebonyi State, Nigeria
}

\begin{abstract}
This study examines the variations in interest rate structure on corporate financial investment decisions in Nigeria. The study spans from the periods 2000-2019. The objective of this research among others is to find out the effect of interest rate variations on corporate financial investments in Nigeria. The study employed a quasi experimental correlation design using an Ordinary Least Square (OLS) method of regression analysis and various tests of significance. The first observation revealed that positive relationship exists between the interest rates and the level of corporate investment decisions. The result of the second regression revealed an inverse relationship which indicates that investment in corporate assets increases with decrease in interest rate. It is pertinent, therefore, to assert from the investigations made, so far that the level of variation in interest rate played a negative but highly significant role in investment decision in the economy. Demand for credit also had negative and significant influence on interest rate variations in both the short run and long run. Although, the study deduced that investment has an indirect relationship with interest rate variation, other variables such as debt income, real income, government spending, aggregate savings and money stock affects gross domestic investment. Improvement in these key macro-economic variables is a necessary condition towards facilitating investment in Nigeria. The researcher recommends inter alia that an essential prerequisite condition needed to promote corporate financial investments is for the government to formulate and implement policies that enhances investments.
\end{abstract}

Key words: Corporate financial investment, interest rate, interest rate variation, investment decisions, economic growth, Nigeria

\section{INTRODUCTION}

The variability of short-term and long-term interest rates is a prominent feature of the Nigerian economy. The Nigeria financial sector reforms of 1986 began with the liberalization of the interest rate which was aimed at enhancing funds mobilization and disbursement of resources, so as to achieve economic growth and development (Obute et al., 2012). According to Keynes, interest rate is the reward for not hoarding but parting with liquidity for a period of time. Keynes definition of the interest rate focuses more on the nominal lending rate rather than any other aspect of interest rate. Adebiyi defines interest rate as the return or yield on equity or the opportunity cost of deferring current consumption into the future. Some examples of interest rate include: the savings rate, the lending rate and the discount rate. Jhingan (2003) defines interest rate as the price which equates the supply of credit or savings plus the net increase in the amount of money in the period to the demand for credit or investment plus "net hoarding" in the period. This definition implies that interest rate is the price of credit which like other prices is determined by the market forces of demand and supply. Banks as intermediaries move fund from surplus units of the economy to deficit units by accepting deposits and channeling them into the appropriate sectors. The extent to which this could be done depends on the rate of interest and level of development of financial sector as well as the saving and investment habit of the people. Hence, the availability of investible fund is therefore, necessary for all investment in the economy which eventually translates to economic growth and development (Uremadu, 2006).

Interest rate policy is among the emerging issues in view of the role it is expected to play in the deregulated economy in inducing savings which can be channeled to investment and thereby increasing employment, output and efficient financial resource utilization. Also, interest rates can have a substantial influence on the rate and pattern of economic growth by influencing the

Corresponding Author: Onuoha, Ijeoma Perpetua, Department of Accountancy and Banking and Finance, Alex-Ekwueme Federal University Ndufu-Alike Ikwo, Ebonyi State, Nigeria, Tel: +2347033548086 
volume and disposition of saving as well as the volume and productivity of investment (Leahy, 1993; Lensink and Morrissey, 2000).

With the adoption of SAP, the regulatory framework guiding the operations of banks changed. Steps were taken to liberalize interest and lending rates. Interest rate liberalization is an economic term used for a situation whereby the forces of demand and supply are allowed to determine the value of the interest rate rather than its value being determined and administered directly by monetary authorities (Obute et al., 2012). Interest rate liberalization is seen as a deviation from financial repression and it has been advocated by scholars that interest rate liberalization helps to enhance savings, boost investment and consequently help to enhance economic growth. Interest rate boosts the level of investment in an economy and as a result interest rate is a major determinant of investment. Interest rate could be referred to as the price paid for the use of money. Investment is the change in capital stock during a period. Investment plays a very important role in economic growth in a country. Countries rely on investment to solve economic problems such as poverty, unemployment, etc. (Yunus, 2004). Interest rate reform is a policy under financial sector liberalization which was intended to achieve efficiency in the financial sector and at the same time enhance investment and financial deepening. In Nigeria, financial sector reforms began with the deregulation of interest rates (Obamuyi, 2009). Prior to this period, the financial system operated under financial regulation and interest rate were said to be repressed (Obamuyi, 2009). Interest rates changes in response to a variety of economic events such as changes in government policies, crises in domestic and international financial markets and changes in the prospects for long-term economic growth and inflation. However, economic events such as these tend to be irregular. There is a more regular variability of interest rates associated with the business cycle, the expansions and contraction that the economy experiences over time. For instance, short-term interest rates rise in expansions and fall in recessions. Long-term interest rates do not appear to co-vary much with the level of economic output. The term cyclical volatility of interest rates refers to the variability of interest rates over periods that correspond to the length of the typical business cycle (Obamuyi, 2009).

The behaviour of interest rate to a very large extent, determines the investment activities and hence, the economic growth of a country. Investment depends upon the rate of interest involved in getting funds from the market, while economic growth to a large extent depends on the level of investment. According to Jhingan (2003) if interest rate is high, then investment will be correspondingly at low level, and when interest falls, investment will invariably rise. There is therefore, the need to promote an interest rate regime that will ensure an inexpensive spending for investment and consequently enhancing economic growth at a very low financial cost (Obute et al., 2012). Prior to the liberalization of interest rate in 1986, the level of interest rate were being administered by the central bank of Nigeria. The power of control and interest rate structure was contained in the banking Amendment Act of 1969. This Act states that the rate of interest charged on advance, loans and credit facilities or interest paid on deposits by licensed commercial banks should be linked with the minimum rediscount rate of the Central Bank of Nigeria (CBN).

The advent of the Structural Adjustment Program (SAP) resulted in the radical departure from the regime of interest rate control and management by the government. It introduced market oriented development process with emphasis on small government interventions, efficient allocation of resources and market-determined price (Obute et al., 2012). Interest rate reform is a policy under financial sector liberalization which was intended to achieve efficiency in the financial sector and at the same time enhance investment and financial deepening. In Nigeria, financial sector reforms began with the deregulation of interest rates. Prior to this period, the financial system operated under financial regulation and interest rate were said to be repressed (Obamuyi, 2009).

Interest rates changes in response to a variety of economic events such as changes in government policies, crises in domestic and international financial markets and changes in the prospects for long-term economic growth and inflation. However, economic events such as these tend to be irregular. There is a more regular variability of interest rates associated with the business cycle, the expansions and contraction that the economy experiences over time. For instance, short-term interest rates rise in expansions and fall in recessions. Long-term interest rates do not appear to co-vary much with the level of economic output. The term cyclical volatility of interest rates refers to the variability of interest rates over periods that correspond to the length of the typical business cycle (Obamuyi, 2009).

The pre- reform period (1970-1986) was considered as a period of financial repression and was characterized by a highly regulated monetary policy economic environment in which policies of directed credits, interests rate ceilings and restrictive monetary expansion were prevalent (Soyibo and Adekanye, 1991). Although, the interest rate was fixed, some marginal increases still exist. For instance, the deposit rate was increased from $3 \%$ in 1975 to $9.5 \%$ in 1986 while the lending rate rose from $9-12 \%$ within the same period (Obamuyi, 2009). The effect of low and negative interest rate is that savings are likely to be discouraged and this will negatively affect fund mobilization by the banks. This invariably will affect the volume of funds made available for investment. On 
the other hand, the high lending rate is detrimental to production. According to Obamuyi (2009), the expectation of interest rate reforms was that it would encourage domestic savings and make loan able funds available in the banking institutions but it was observed that the interest rate structure has been' tunnel like' in Nigeria and this is capable of discouraging savings and retarding growth in view of the empirical link between savings, investment and interest rate. The implication of the tunnel like structure of the interest rates and the low interest rates are that savings will likely be discouraged and this will likely affect funds mobilization by banks. This will in turn affect the amount of funds available for investment.

Okereke (2003) equally defined investment to include all economic activities designed to increase, improve or maintain the productive quality of an existing stock of capital. Generally, investment could be in real or financial assets. It is real assets if the investments are done in capital equipment and properties and financial assets if it is on shares, treasury bills and bonds. This type of asset forms the basis for this study but excludes the treasury bills which are short term investment. The financial asset can in other words be referred to as financial investment (Aborode, 2004). Financial investment done by corporate organizations in a bank or other firms is known as corporate financial investment. According to Okereke (2003), apart from factors such as income of the people, Investment opportunities available, alternative uses and savings which can influence corporate financial investment, other factors like interest rate plays a major role in determining the volume of investment in an economy.

The variation of interest rates affects decisions about how to save and invest. This invariably has a negative impact on the quantity and the quality of investment and hence economic growth and development. Investors differ in their willingness to hold risky assets such as bonds and stocks. When the returns to holding stocks and bonds are highly volatile, investors who rely on these assets to provide their consumption face a relatively large chance of having low consumption at any given time. For example, before retirement, people receive a steady stream of income that helps to buffer the changes in wealth associated with changes in the returns on their investment portfolios. This steady return from working helps them maintain a relatively steady level of consumption. After retirement, people no longer have the steady stream of income from working hence a less volatile investment portfolios is called for. The lower volatility of investment returns allows retirees to maintain a relatively even level of consumption overtime.

Prior to 1986, the Central Bank of Nigeria (CBN) had already fixed the interest rates which resulted in very low interest, this decision was informed by the need to encourage investment. However, the regulation of interest rate did not achieve the desired positive result for which it was meant since the problem of financial repression prevailed despite all the effort made, so far. In 1984 for instance the rate of inflation was at the high rate of $39.6 \%$ which was far above the savings rate of $5 \%$ and prime lending rate of $9.25 \%$, respectively in the same year. igeria experienced severe macroeconomic problems towards the end of 1970's through the first half of the 1980s when output declined substantially. The real GDP growth rate averaged only $1.5 \%$ per annum during the period 1973-1980 (registering negative growth rate in 6 years during the period) (CBN, 2003). In response to this deteriorating economic situation, the Nigerian authorities launched policy programs contained in the Structural Adjustment Program (SAP). The advent of the structural Adjustment program in the third quarter of 1986 ushered in an era of interest rate deregulation. Within the reform period, interest rates were allowed to be determined by the market forces of demand and supply and the interest rate actually increased as envisaged. Several forms of corrective measures were undertaken including financial sector reform policies.

Prior to 1986 in Nigeria, a common practice has been the support of certain economic projects considered to be essential part of developmental strategy. Government adopted policies aimed at accomplishing specified objectives such as interest rate ceilings and selective sectoral policies. Those policies were introduced with the intension of directing credit to priority sectors and securing inexpensive funding for their own activities. The ceiling on interest rates and quantitative restrictions on loanable funds for certain sectors ensure that larger shares of funds are made available for favoured sectors. Such practice hinders financial intermediation, since, the financial markets will only be accommodating the credit demands of the government plan and ignoring risks. The practice has not been favoured as a growth policy by the repressionist school led by McKinnon (1973). According to their financial repression paradigm; government's efforts to promote economic growth by such indiscriminate measures have repressed the financial system. This by implication discourages financial intermediation. Thus, the repressionist school calls for financial liberalization, the removal of ceiling on interest rates, among others as a growth promoting policy. According to them, the removal of interest rates ceiling will raise savings rates because the interest elasticity of private savings is positive. The interest rate policy in Nigeria is perhaps one of the most controversial of all financial policies. The reason for this may not be farfetched because interest rate policy has direct bearing on many other economic variables such as investment decision. Interest rates play a crucial role in the efficient allocation of resources aimed at facilitating growth and 
development of an economy and as a demand management technique for achieving both internal and external balance.

Generally, the behavior of interest rate structure is such that there is a wide spread margin between deposit and lending rates which may encourage speculative financial transaction. The policy shift de emphasized direct investment stimulation through low interest rates (Albu, 2006). To date, Nigeria has pursued two-interest rate regime. The 1960 's to mid-1980s with the administration of low interest rates which was intended to encourage investment. However, the advent of the Structural Adjustment Program (SAP) in the third quarter of 1986 ushered in an era when fixed and low interest rates were gradually replaced by a dynamic interest rate regime, where rates were more influenced by market forces. Hence, the pursuit of the two interest rate regime in Nigeria provided a case study of the Keynesian interest-rates-investment relationship and the McKinnon (1973) interest and investment hypothesis.

The gradual deregulation of the Nigerian economy between 1986 and 1992 affected these key economic variables interest rates and investment. In the Nigerian context, interest rates were extensively regulated prior to the adoption of SAP in 1986. But the economic rationale behind this control of interest rates and other elements of financial markets has been motivated by a variety of factors including the desire to influence the flow of credit to preferred sectors of the economy and the concern that market determined interest rate could result in serious imperfection in the market. Moreover, the upsurge in real interest rates observed worldwide in the early 1980's has raised widespread concern about their possible detrimental economic effects. Therefore, in response to these concerns, numerous studies were carried out to measure the effect of high interest rate on the key macroeconomic variables. Nevertheless, the concurrent increase in interest rates resulting from the deregulation seems to lay credence to McKinnon (1973) interest rate and investment hypotheses.

The main thrust of this study is to examine what happens to investment with variation in interest rates and the relationship between short-term and long-term interest rate and investment in Nigeria. This is necessitated by the fact that previous studies in this area never examined interest rate variations and its effect on corporate financial investment in Nigeria and the more reason that investment which is the demand for credit might have impact on the determination of interest rate. This study therefore, intends to examine the effect of interest rate variation on corporate financial investment in Nigeria using a quasi experimental research design.

Statement of problem: Nigeria is faced with the problem of insufficient level of corporate financial investment in virtually all the sectors of the economy. The federal government has adopted different policy measures with the intention of determining a reasonable level of interest rates so as to attract required capital or savings that could be loaned to the investing public. With the policy of deregulation, interest rates were allowed to be determined by the market forces of demand and supply. Banks were given the freelance to negotiate the interest on time deposit. The resultant effect of this was a sharp increase in both merchant and commercial banks lending rates. The presence of this factor which apparently was expected to bring about a sharp decline in the interest rates structure, did not achieve the desired change, instead, the lending and deposit interest rates were increasing without a corresponding increase in the level of corporate investment. The era of interest rate deregulation was not better off even, this is because frequent instabilities of the interest rate did not encourage the entrepreneurs to plan ahead and this led to an unprecedented increase in the cost of capital. Access to credit in the country deteriorated overtime which lead to low investment.

The two different eras of interest rate structures in the Nigerian economy was indeed a source of concern as corporate financial investment kept deteriorating. The fact that interest rate and corporate investment are related as postulated by interest rate theorists is a problem. Also, there is a problem of whether to continue regulating the interest rates by the $\mathrm{CBN}$ or not. This is because contributions of these interest rates to economic growth are in doubt since a sustainable high level of investment cannot be achieved. Over the years, achieving sustainable growth and development in Nigeria has been very challenging. There has been low level of savings and investment, instability in Monetary and Fiscal Policies, Falling Crude Oil Prices in the International Market, High level of interest rate and Poor infrastructural development amongst others. As a result of the instability in the country, the Nigerian Government with the aid of the International Monetary Fund adopted the Structural Adjustment Program in 1986. The aim was to restructure the productive and consumption patterns of the economy through the elimination of price distortions and reduction in the dependency on crude oil export and import of raw materials and consumer goods. Prior to the introduction of the Structural Adjustment Program in Nigeria in 1986, the Monetary Authority, the Central Bank determined interest rate with a specific range between deposit and lending rates. Banks were required to channel specific percentage of their credits to the priority sectors of the economy. The Agricultural and Industrial sectors were the priority as well as the productive sectors of the domestic economy and despite these measures put in place by the Government, stimulating the productive sectors of the economy have not been achieved. Interest rate has been 
unstable and high level of investment has not yet been achieved as far as the Nigerian economy is concerned. This therefore, is a justification to examine the effect of interest variation on corporate financal investment decisions in Nigeria for a period of seventeen years (2000-2019).

Objectives of the study: The broad objective of this study is to determine the effect of interest rate variation on corporate financial investment decisions in Nigeria. The specific objectives are:

- To determine the effects of Real Income (RI) on the level of corporate financial investment decisions in Nigeria

- To ascertain the effect of Debt Income (DI) on corporate financial investment decisions in Nigeria

- To examine the effect of Exchange Rate (EXR) on corporate financial investment decisions in Nigeri

- To investigate the effect of Money Stock (MS) on corporate financial investment decisions in Nigeria

- To analyze the effect of Government Spending (GSP) on corporate financial investment decisions in Nigeria

- To examine the effect of Aggregate Savings (ASV) on corporate financial investment decisions in Nigeria

Statement of hypothesis: The hypothesis that will guide this study was stated in a null form and in line with the objectives of this study:

- $\mathrm{Ho}_{1}$ : there is no significant relationship between Real Income (RI) and corporate financial investment decisions in Nigeria.

- $\mathrm{Ho}_{2}$ : there is no significant relationship between Debt Income (DI) and corporate financial investment decisions in Nigeria.

- $\mathrm{Ho}_{3}$ there is no significant relationship between Exchange rate (EXR) and corporate financial investment decisions in Nigeria.

- $\mathrm{Ho}_{4}$ : there is no significant relationship between Money Stock (MS) and corporate financial investment decisions in Nigeria

- $\mathrm{Ho}_{5}$ : there is no significant relationship between Government spending (GSP) and corporate financial investment decisions in Nigeria

- $\mathrm{Ho}_{6}$ : there is no significant relationship between Aggregate savings (ASV) and corporate financial investment decisions in Nigeria

Significance of the study: The knowledge provided by this study will to a very large extent provide improved body of literature on interest rate variations and corporate investment decisions in Nigeria. It will also contribute significantly to theoretical justification. Again the outcome of this study is expected to be of immense benefit to accountants, bankers, policy makers, governments, researchers as well as institutions that may be interested in interest rate structure in Nigeria for corporate investment purposes. However, if the policy measures as may be recommended by the study is adopted and implemented by the government, they will in no small measure improve corporate financial investment thus accelerating growth in the national economy.

Scope of the study: This study examines the variations in interest rate structure on corporate financial investment decisions in Nigeria between the periods 2000-2019. The annual variance of interest rate from monthly interest rate data for the period under review was calculated, so as to examine the determinants of interest rate variation and its impact on investment decisions. The study employed a quasi experimental correlation design using Ordinary Least Square (OLS) method of regression analysis and various tests of significance.

Empirical reviews: Despite the saturation of literatures with studies on exchange rate volatility, the lists are still very scanty with respect to developing countries. It is imperative to note from the literatures, so far that interest rate policy is among the emerging issues in current economic policy in Nigeria in view of the role it is expected to play in the deregulated economy in inducing savings which can be channeled to investment and thereby increasing employment, output and efficient financial resource utilization. Also, interest rates can have a substantial influence on the rate and pattern of economic growth by influencing the volume and disposition of saving as well as the volume and productivity of investment.

Obamuyi (2009) studied the relationship between interest rate and economic growth in Nigeria. The study employed cointegration and error correction modeling techniques and revealed that lending rate has significant effect on economic growth. The study then postulated that investment friendly interest rate policies necessary for promoting economic growth needs to be formulated and properly implemented. Studied interest rate and investment behavior in Nigeria from the period 1976-2006 using time series data, he found out that investment has a significant influence on interest rate and inflation rate.

Ologunde et al. (2006) examined the relationships between stock market capitalization rate and interest rate in Nigeria. They used the Ordinary Least-Square (OLS) regression method and they found that the prevailing interest rate exerts positive influence on stock market capitalization rate. 
Albu (2006) studied trends in the interest rate, investment, GDP growth relationship. The study used two partial models to examine the impact of investment on GDP growth and the relationship between interest rate and investment in the case of the Romanian economy. The study found that the behavior of the national economy system and interest rate-investment relationship tend to converge to those demonstrated in the normal market economy.

Greene and Villanueva (1991), estimated the effect of macroeconomic variables and policies including interest rates on private investment on a group of developing countries. Their results showed that private investment-GDP ratio is positively related to real GDP growth level of per capita income and rate of public sector investment while interest rate, domestic inflation negatively affect private investment ratio.

Eregha (2010) examined variations in interest rate and investment determination in Nigeria and found out that investment has an indirect relationship with interest rate variation and other variables that he used.

Soyibo and Adekanye (1991) observed that borrowers with worthwhile investments may be discouraged from seeking loans and the quality of mix of applicants could change adversely. The high lending rate also could create moral hazards where loan seekers borrow to escape bankruptcy rather than to invest or finance working capital. Soyibo and Adekanye (1991) also noted that investment is an addition to capital such that will occur when a new house is built or a new stock of goods is in existence.

\section{MATERIALS AND METHODS}

Research design: This study adopts a quasi-experimental research design and the ordinary least square method of regression analysis. This research design is useful considering the fact that the researcher intends to analyze a time series data spanning from 2000-2019. This design, however, relates to the setting up of a particular type of an experiment or other study in which one has little or no control over the allocation of the treatments or other factor being studied. The key difference in this empirical approach is the lack of random assignment. Another unique element often involved in this experimentation method is the use of time series analysis. However, the first part of creating a quasi experimental design is to identify the variables. The quasi independent variable will be the $\mathrm{x}$-variable, the variable that is manipulated in order to affect a dependent variable. X-variable is generally a grouping variable with different levels. Grouping, here, means two or more variables fused together to form independent variables. The predictable outcome is the $y$-variable. In a time series analysis (as applied in this study), the dependent variable is observed over time for any changes that may take place. One of the merits of this design is that it minimizes threat to external validity as natural environments do not suffer the same problem of artificiality as compared to a well controlled laboratory setting. Finally, this design is efficient in longitudinal research that involves longer time periods which can be followed up in different environments.

Data requirements and sources: The data was exclusively generated from the quantitative time series data on corporate investment and the interest rates of commercial banks for the period under review. Data for corporate financial investment was extracted from purchases of investment activities of the cash flow statements as contained in the annual financial reports of commercial banks as published by the banking supervision department under the monetary policy committee and Debt Management Office (DMO) of the CBN while the data for exchange rate variation was extracted from CBN statistical bulletin for the various years of study. The independent variable which is represented as (x) which constitute factors arising from interest rate variation such as Exchange Rate (EXR), Government Spending (GSP), Aggregate Savings (ASV); while the dependent variable represented as $(\mathrm{y})$ is proxied by the long term corporate financial investment variables such as (Real Income (RI), Debt Income (DI), Money Stock (MS). This research is a quantitative research and as such the researcher adopted the ordinary least square method of econometric model involving a simple regression analysis.

Model specification: The empirical analysis of the effect of interest rate variation on corporate financial investment decisions in Nigeria is often accomplished using regression analysis which can be explicitly or implicitly stated based a theoretical framework of endogenous models (Kings and Levine, 2004). The independent variable which is represented as (x) constitute factors arising from interest rate variation such as Exchange Rate (EXR), Government Spending (GSP), Aggregate Savings (ASV) while the dependent variable represented as (y) is proxied by the long term corporate financial investment variables such as (Real Income (RI), Debt Income (DI), Money Stock (MS).

Interest rate variables: Besides the theoretical hypotheses of Keynesian liquidity preference, the classical and the loan able funds theories of interest rate, the CBN postulated that interest rate behaviour depends on savings (supply of credit), investment (demand for credit), government spending, money supply (monetary policy) and taxation. For the purpose of this study, the independent variable is represented as (x) and which constitute factors arising from interest rate variation such as Exchange Rate (EXR), Government Spending (GSP) and Aggregate Savings (ASV). 
Investment variables: Based on the combination of all the theories of investment ranging from the classical to Keynesian, they found a positive effect of interest rate variation on corporate financial investment but this was confined to smaller firms rather than larger firms. The dependent variable represented as $(y)$ is proxied by the long term corporate financial investment variables such as Real Income (RI), Debt Income (DI) and Money Stock (MS). While the independent variable (x) is proxied by interest rate variables such as Exchange Rate (EXR), Government Spending (GSP), Aggregate Savings (ASV).

If these assumptions are right, then a multiple linear regression analysis can be adopted and specified thus:

$$
\begin{gathered}
\mathrm{Y}=\mathrm{f}(\mathrm{x}) \\
\mathrm{INV}=\mathrm{f}(\mathrm{INT}) \\
\text { RI, DI, MS }=\mathrm{f}(\mathrm{EXR}, \mathrm{GSP} \text { and ASV })
\end{gathered}
$$

Where:

RI : Real income
DI : Debt income
MS : Money stock
EXR : Exchange rate
GSP : Government spending
ASV : Aggregate savings

Therefore, we can re-write (Eq. 2) in its stochastic explicit form based on the functional relation as follows:

$$
\text { RI, DI, MS }=\text { EXR, GSP and ASV }
$$

$$
\mathrm{RI}, \mathrm{DI}, \mathrm{MS}=\alpha_{0}+\alpha_{1} \mathrm{EXR}+\alpha_{2} \mathrm{GSP}+\alpha_{3} \mathrm{ASV}+\mathrm{U}_{\mathrm{t}}
$$

All variables are as previously defined.

Where:

$\alpha_{0} \quad:$ The regression constants

$\alpha_{1}, \alpha_{2}$ and $\alpha_{3}$ : The parameter coefficients and

$\mathrm{U}_{\mathrm{t}} \quad$ : The stochastic error term obtain:

Transforming Eq. (3) into a natural logarithm, we can

InRI, InDI, InMS $=\alpha_{0}+\alpha_{1} \operatorname{InEXR}+\alpha_{2}$ INGSP $+\alpha_{3} \operatorname{InASV}+\mathrm{U}$

Thus, the transformed log linear Eq. (4) will be estimated using the Ordinary Least Square (OLS) method of regression analysis. The use of $\log$ linear method improves the validity of the estimates. This method also reduces, if not completely removes the hetrosdaciticy errors which may result from unscaled magnitude on both sides of the equation. The model is a log-linear specification.
Where:

$\alpha_{0} \quad$ : Intercept

$\alpha_{1}-\alpha 3$ : Coefficients

$\alpha_{3}$ : Short run coefficient of interest rate on investment

INV : Investment coefficient

INT : Interest rate coefficient

EXR : Exchange rate

RI : Real income

GSP : Government spending

ASV : Aggregate savings

MS : Money stock

DI : Debt income

$\mathrm{U}_{\mathrm{t}} \quad$ : Stochastic error terms

$\mathrm{t} \quad$ : End of period

Analytical estimation method: The model developed in this study is a time series linear regression model which is estimated using the Ordinary Least square (OLS) method of regression analysis with the help of E-view 9.0 econometric package. The use of ordinary Least Square method, according to Koutsiannis (2003) makes the parameter estimated very simple, unbiased and efficient. Regression analysis is a statistical process used in estimating the relationship between variables. It includes many techniques for modeling and analyzing several variables when the focus is on the relationship between a dependent variable and one or more independent variables. In this study, the level of interest rate variations on corporate financial investment is assumed to be influenced by several variables of ' $y$ ' which represents the long term corporate financial investment decision variables proxied as Real Income (RI), Debt Income (DI) and Money Stock (MS) while ' $\mathrm{x}$ ' is represented by some factors arising from interest rate variations which were proxied as Exchange Rate (EXR), Government Spending (GSP), Aggregate Savings (ASV).

Tables were used to analyze some descriptive statistics of the interest rate variation and investment decision variables. The mean values for both the dependent and independent variables were shown in the regression result which revealed the ones with the highest and least variability as well as the standard errors. The F and T-ratios were used to test for the statistical significance of the regression coefficients. The coefficient of determination $\mathrm{R}^{2}$ was used to measure the goodness of the fit while Durbin-Watson statistics was employed to determine the nature of autocorrelation among the variables.

Validity and reliability of the instruments used: To ensure the validity and reliability of the instruments used, the researcher specifically made use of the Ordinary Least Square method (OLS) method of regression analysis to analyze and interprete the data employed in this study. This analytical technique was employed because it is the 
Int. Business Manage., 13 (9): 381-391, 2019

Table 1: Result of interest rate variation variables

\begin{tabular}{lcccc}
\hline Variable & Coefficient & SE & t-Statistic & Prob. \\
\hline $\mathrm{C}$ & 2.23 & 0.230 & 1.08 & 0.000 \\
$\mathrm{Lg}(\mathrm{EXR})$ & 0.32 & 1.076 & 0.97 & 0.002 \\
$\mathrm{Lg}($ GSP $)$ & 0.01 & 0.786 & 0.35 & 0.000 \\
$\mathrm{Lg}($ ASV $)$ & 0.01 & 0.095 & 0.35 & 0.001 \\
\hline
\end{tabular}

$\mathrm{R}^{2} 0.86$ Mean Dependent variable 2.09; Adjusted $\mathrm{R}^{2} 0.86$ SD Dependent variable 0.07; SE of regression 0.23 Akaike info criterion 1.32; Sum squared resid 0.27 Schwarz criterion 1.01 Log likelihood 1.08 F-Statistic 31.76 Durbin-Watson stat 2.24 Probability (F-Statistic) 0.0000 Inverted MA Roots .86 E-view 9.0 Computer result Dependent Variable: Lg (INT) Ordinary Least Square method Date: 04/02/19Time: 12:23 pm Sample (adjusted): 2000-2019 Included observations: 10 after adjusting endpoints convergence achievement after 5 iterations

best linear and unbiased method of estimation. Also, the E-view 6.0 econometric package was employed to analyze the descriptive statistics because it is one of the most recently used regression packages with the use of this regression package, analysis and interpretation is self explanatory. The researcher employed the $t$-values and the signs of the coefficients of some descriptive statistics of the interest rate variation and investment decisions such as Real Income (RI), Debt Income (DI), Money Stock (MS), Exchange Rate (EXR), Government Spending (GSP) and Aggregate Savings (ASV) for the analysis. The empirical results, test of hypotheses, computations and validities were ascertained by my supervisor who reviewed the work for confirmation and approval.

Method of data analysis: This study employed econometric techniques of ordinary least square method of regression analysis to estimate the relationship between dependent and the independent variables. This segment presents the empirical data employed in the conduct of this study. The data was exclusively generated from the quantitative time series data on corporate investment and the interest rates of commercial banks for the period under review. Data for corporate financial investment was extracted from purchases of investment activities of the cash flow statements as contained in the annual financial reports of commercial banks as published by the banking supervision department under the monetary policy committee and Debt Management Office (DMO) of the CBN while the data for exchange rate variation was extracted from $\mathrm{CBN}$ statistical bulletin for the various years of study. The empirical results obtained after the diagnostic test were also presented in Table 1 and 2 respectively.

The spurious nature of the ordinary least square regression model: $\mathrm{R}$-square is a statistical measure of how close the data are to the fitted regression line. It is also known as the coefficient of determination for multiple regressions. The R-square is the percentage of the response variable variation that is explained by a linear model or Explained/Total Variation. In general, the higher the R-square, the better the model fits your data but
Table 2: Result of corporate financial investment decisions variables \begin{tabular}{lllll}
\hline Variable & Coefficient & SE & t-Statistic & Prob.
\end{tabular} \begin{tabular}{lllll}
\hline $\mathrm{C}$ & 0.32 & 0.600 & 3.99 & 0.000
\end{tabular} $\begin{array}{lllll}\mathrm{Lg}(\mathrm{RI}) & 1.36 & 0.361 & 4.73 & 0.003\end{array}$ $\begin{array}{lllll}\mathrm{Lg}(\mathrm{DI}) & 0.14 & 0.064 & 0.21 & 0.000\end{array}$

$\begin{array}{lllll}\mathrm{Lg}(\mathrm{MS}) & 0.02 & 0.564 & 0.07 & 0.005\end{array}$
$\mathrm{R}^{2} 0.96$ Mean Dependent variable 2.00 Adjusted $\mathrm{R}^{2} 0.63$ SD Dependent variable $0.15 \mathrm{SE}$ of regression 0.32 Akaike info criterion 1.51 Sum squared resid 0.29 Schwarz criterion 1.23 Log likelihood -1.06 F-Statistic 139.79 Durbin-Watson stat 1.69 Probability (F-Statistic) 0.0000 Inverted MA Roots 0.96 E-view 9.0 Computer result; Dependent Variable: Lg (INV) Method: Least Squares Date: 05/02/19Time: 10:23pm Sample (adjusted): 2000- 2019 Included observations: 10 after adjusting endpoints Convergence achievement after 5 iterations

you can also have a low R-square value for a good model, or a high R-square value for a model that does not fit the data. If the $\mathrm{R}$-squared value is low but you have statistically significant predictors, you can draw important conclusions about how changes in the predictor values are associated with changes in the response value. A spurious regression model may have a very high $\mathrm{R}^{2}$, $\mathrm{t}$-statistics that appear to provide significant estimates but the results may have no economic meaning. Granger and Newbold proposed the following 'rule of thumb' for detecting spurious regressions: If $\mathrm{R}^{2}>\mathrm{DW}$-statistic or if $\mathrm{R}^{2}=1$, then the regression 'must' be spurious. The regression result presented in Table 1and 2 shows an estimated regression line with corporate financial investment decision variables proxies such as Real Income (RI), Debt Income (DI) and Money Stock (MS) as the dependent or outcome variable with Exchange Rate (EXR), Government Spending (GSP) and Aggregate Savings (ASV) as the explanatory or independent variables. The result in table 1 shows that the regression is not spurious since the $R^{2}$ of 0.23 is low and also not approximately 1 . However, the $\mathrm{R}^{2}$ statistics is less than the DW. The foregoing therefore implies that any conclusion drawn based on this result will be considered valid and statistically consistent.

Presentation of empirical data: To achieve the stated objectives of this study, annual time series data of the variables stated in the previous chapter were employed. For the purpose of this study, the profits before taxes of the annual time series data were used. The period covered by the study is 2000-2019. The choice of the period was informed by the developments and changes in the exchange rate structure of the Nigerian economy as it affects corporate financial investment decisions in Nigeria. Specifically, the data were tested for Stationary status by conducting a unit root test using the Dickey-Fuller (DF) and Augmented Dickey-Fuller (ADF) test. In Table 1 and 2, the data used for the conduct of this study.

\section{RESULTS AND DISCUSSION}

The data used for estimating the model are mainly from secondary sources which were extracted from the 
CBN Statistical Bulletin. The estimation is done with the use of E-view 6.0 econometric package. The inclusion of other variables to complement interest rate and investment is to avoid the specification problem which is capable of biasing estimation results and complicating policy formulation. The subsequent section will elaborate on the presentation and analysis of the results. The estimation results of the model are shown in tabular form followed by a detailed analysis. Using relevant data obtained for each variable for the period 2000-2019, it is estimated using linear programming technique to obtain the parameter estimates. The summary results obtained are shown in Table 1 and 2.

In Table 1 , the $\mathrm{R}^{2}$ indicates that all the explanatory variables account for $86 \%$ of the variation in interest rate during the sample period. The F-value of 31.76 which is significant at the $1 \%$ level indicates considerable harmony in the relationship between interest rate and the explanatory variables put together. The Standard Error of Regression of 0.23 and Durbin Watson (DW) statistic of 2.24 imply minimal estimation error and auto-correlation which are good attributes of econometric estimation results. Table 1 , shows that all the explanatory variables are well behaved as the signs of their coefficients are in conformity with apriori expectations of the model. A careful examination of the result indicates that money stock has a short-run coefficient of 0.02 and $\mathrm{t}$-value of 0.47 .

In Table 2, the value of $\mathrm{R}^{2}$ in the estimation indicates that all the explanatory variables account for $96 \%$ of the variation in investment during the sample period. The F-value of 139.79 which is significant at the $1 \%$ level shows that there exists a strong linear relationship between investment and the explanatory variables combined together. The Standard error of regression of 0.32 and Durbin Watson (DW) statistic of 1.69 imply minimal estimation error and auto-correlation which are good attributes of econometric estimation result. Table 2 shows that all the explanatory variables except debt-income ratio as a measure of debt-overhang hypothesis are well behaved as the signs of their coefficient are in conformity with apriori expectations of the model. A proper examination of the result shows that Real Income (RI) has a short-run coefficient of 1.36 and $\mathrm{t}$-value of 4.73 which is significant at the $5 \%$ level. The long run coefficient with respect to investment is calculated to be 2.57 ; it means that the long run elasticity of investment with respect to income is 2.57 . The study also indicates a short run coefficient of interest rate to be 0.32 and t-value of 3.99 which is also significant at the $5 \%$ level. The long run coefficient is calculated to be. 0.61 meaning that a $10 \%$ change in interest rate in the long run will generate $61 \%$ change in investment decision. The short run coefficient of exchange rate is 0.32 and $t$-value of 0.97 which is not significant. The investment equation estimated has clearly shown that changes in interest rate and income are key determinants of investment decision which are also significant at the $5 \%$ level.

Findings: This research empirically examined the effect of interest rate variation on corporate financial investment decisions in Nigeria from year 2000-2019. Financial Investment decision variables served as the Dependent variables proxied as Real Income (RI), Debt Income (DI) and Money Stock (MS) while Exchange Rate (EXR), Government Spending (GSP) and Aggregate Savings (ASV) served as proxies for the independent variables. The multiple regression method of econometrics was employed in the estimation. Based on the analysis made so far, the long-run coefficient is calculated to be 0.07 which means that a $10 \%$ change in money stock in the long-run would generate $7 \%$ change in interest rate. The coefficient of investment has a short-run coefficient of 0.07 and $t$-value of 3.51 which is highly significant at the $5 \%$ level and has negative effect on interest rate. The long run coefficient is calculated to be 0.24 meaning that a $10 \%$ change in investment in the long run would generate or cause $24 \%$ change in interest rate. The coefficients of government spending and aggregate savings as well as their t-values in parenthesis are $0.01(0.35)$ and 0.11 $(0.16)$ with their long run coefficients of 0.03 and 0.38 , respectively. It could be deduced that a $10 \%$ change in the long run of government spending and aggregate savings in the economy would generate 3.0 and $38 \%$ change, respectively on interest rate. The estimation has clearly shown that investment decisions play a negative role in interest rate which is significant at the 5\% level and it shares this status with government spending which is though not significant at the $5 \%$ level. The other variables (Aggregate savings and Money stock) are indicated to have played positive role in interest rate though they are not statistically significant at $5 \%$ level.

\section{CONCLUSION}

In this research, an attempt was made to investigate the variation in interest rate and financial investment decisions in Nigeria. The investigation covers the period 2000-2019 and employed the Ordinary Least Square (OLS) Method of regression analysis. A theoretical analysis was first undertaken to explain the relationship between changes in interest rate and investment decision with explanatory variables affecting both interest rate changes and investment followed by an empirical analysis that discussed estimation results. The study revealed that investment decision played a negative and significant role in interest rate behaviour in the short run and long run. However, aggregate savings and money stock played a positive role but they are not significant in interest rate changes in the sample period. It was also inferred that 
government spending played a negative role but not significant in interest rate change in the economy. Secondly, the study revealed that variation in interest rate played a negative role and highly significant in investment decision in the economy. In other words, it has negative impact on investment decision both in the short run and long run investment decision. The other determinants being income played a positive role and it is highly significant in the short run and long run on investment decisions. Lastly, it was inferred from the study that exchange rate played a positive but not significant role in investment decision in the short run and long run. Having concluded the investigation between the variables under the study period, the study found out that there exist an inverse relationship between interest rate variation and corporate financial investment decisions in Nigeria. The study concludes that since financial Investment plays a vital role in stimulating the economy, therefore, it does not only depend on interest rate variation alone but on other factors as well. We therefore postulate interest rate reform should be a component of the broad package aimed at facilitating financial inter-mediation and monetary management as well as enhancing economic growth in developing countries. However, in high inflation countries like Nigeria, a strong and credible stabilization program and an equally strong set of prudential guide lines are generally the best initial policy measures. Also, there is a need to review on a continuous basis interest rate developments even after liberalizing with a view to ensuring that level and structure of interest rates are adequate and consistent with policy objectives and that the unfolding scenario is suited to the circumstance of the country in which the reform is taking place. Although, the empirical findings shows that investment has an indirect relationship with interest rate variation, other variables such as debt burden, economic stability, foreign exchange, shortage and lack of infrastructure affect gross domestic investment. Improvement in these key macro-economic variables is a necessary condition towards facilitating investment in Nigeria. Also, government should provide sound macro-economic environment by ensuring a non-distortionary but competitive tax system, low inflation rate through prudential fiscal and monetary policies, as well as a stable but non-misaligned interest rate. Nothing can distort investment more than an uncertain or highly volatile macro-economic environment. Perhaps, of great importance for the profitability of investment are the issue of efficient infrastructures and the availability of skilled labour. The financial sector should also be developed to encourage more loan availability. Moreover, strict guidelines should be made to ensure that loans are utilized for the purpose for which they are meant for.

\section{RECOMMENDATIONS}

Having reviewed the effect of interest rate variation on corporate financial investment in Nigeria, the researcher would like to make the following recommendations based on the findings. The major thrust of interest rate policy should be to promote financial intermediation as a way of controlling and promoting efficient allocation and liberalization of financial assets. Monetary policies should be administered to favour other factors other than interest rate, so as to ensure continued increase in financial investment.

A good criterion for promoting corporate financial investment is for the government to formulate and implement financial policies that will enhance investment friendly rates of interest and take into consideration those other factors which negatively affect corporate financial investment in Nigeria.

Government should endeavor to address issues such as economic instabilities, inadequate information on investment, availability of investment opportunities and public safety in channeling financial savings into productive investment, so as to ensure increase in the productive sector of the economy.

A guided deregulation of interest rate should be maintained to ensure moderate credit and monetary expansion which will not distort investment and the general price level. That is to say that monetary and credit policies should be designed in such a way as to entrench a competitive, flexible and more effective regime of economic management.

Effort should be geared towards reversing the weak relationship that exist between interest rates and corporate financial investment, so as to solve the problem of financial repression in the country by ensuring real interest rates reform which can impact heavily on investment.

\section{ACKNOWLEDGEMENT}

I would want to express my profound gratitude to my husband, Dr, Onuoha S.C for his unrelenting support and encouragement in the completion of this research work. Also, my immense gratitude goes to my kids Michelle, Nadia and Dominion and little baby Winifred for their various contributions in inspiring me to achieving greater heights in my academic pursuits. I also would want to say a very big thank you to my co-authors Theresa, Nnenna Uwakwe; Oko, Roseline Ali and Dr. Chinazor, Franca Obi of the Department of Accountancy and Banking/Finance and the Department of Business Administration Alex-Ekwueme Federal University, Ndufu-Alike Ikwo, Nigeria. This research work would not have been completed without the contributions of each and every one of them. 


\section{REFERENCES}

Aborode, R., 2004. A Practical Approach to Advanced Financial Accounting. El-Toda Ventures, Lagos, Nigeria, Pages: 462.

Ajayi, M., 2005. Banking sector reforms and bank consolidation: Conceptual framework. CBN Bullion, 29: 2-10.

Albu, L.L., 2006. Trends in the interest rate-investment-GDP growth relationship. Rom. J. Econ. Forecasting, 3: 5-13.

Eregha, P.B., 2010. Interest rate variation and investment determination in Nigeria, Int. Bus. Manage., 4: 41-46.

Greene, J. and D. Villanueva, 1991. Private investment in developing countries: An empirical analysis. Staff Pap., 38: 33-58.

Jhingan, M.L., 2003. Macroeconomic Theory. 11th Edn., Vrinda Publications (P) Ltd., Delhi, India, ISBN: 9788187125457, Pages: 420.

King, R.G. and R. Levine, 1992. Financial indicators and growth in a cross section of countries. Pre Working Paper No. 819. World Bank, Washington DC., USA. http://documents.worldbank.org/curated/en/316371 468767079250/Financial-indicators-and-growth-ina-cross-section-of-countries

Koutsoyiannis, A., 2003. Theory of Econometrics. Harper and Row, New York, USA.,.

Leahy, J., 1993. Investment in competitive equilibrium: The optimality of myopic behavior. Q. J. Econ., 108: 1105-1133.
Lensink, R. and O. Morrissey, 2000. Aid instability as a measure of uncertainty and the positive impact of aid on growth. J. Dev. Stud., 36: 31-49.

McKinnon, R.I., 1973. Money and Capital in Economic Development. Brookings Institution Press, ?Washington, USA., ISBN:9780815756132, Pages: 184.

Obamuyi, E.O., 2009. An economic study of fixed capital and investment behaviour in Nigeria manufacturing industries. Niger. J. Econ. Social Stud., 26: 271-272.

Obute, C., A. Adyorough and A.I. Itodo, 2012. An assessment of the impact of interest rates deregulation on economic growth in Nigeria (1964-2009). J. Mange. Entrepreneurial Dev., 2: 9-30.

Okereke, A.O., 2003. Financial Accounting Didactic and Detailed Approach. Smash and Company Ltd., Lagos, Nigeria, Pages: 463.

Ologunde, A.O., D.O. Elumilade and T.O. Asaolu, 2006. Stock market capitalization and interest rate in Nigeria: A time series analysis. Intl. Res. J. Finance Econ., 4: 154-166.

Soyibo, A. and F. Adekanye, 1991. The real interest rate in Nigeria: Its measurement and implications for monetary policy. Nig. Financial Rev., 1: 27-44.

Uremadu, S.O., 2006. The impact of real interest rate on savings mobilization in Nigeria. Ph.D. Thesis, Department of Banking and Finance, University of Nigeria, Nsukka, Nigeria.

Yunus, M., 2004. Grameen Bank, microcredit and millennium development goals. Econ. Political Weekly, 39: 4077-4080. 